\title{
Challenges of Small Poultry Farms in Layer Production in Ikwuano Local Government Area of Abia State, Nigeria.
}

\section{Desafíos de las pequeñas granjas avícolas en la producción de capas en el área del gobierno local de Ikwuano del estado de Abia, Nigeria.}

\author{
Ogba, $\mathrm{O}^{1}$ Ahaotu, E. $\mathrm{O}^{1, *}$ Ihenacho, R.O $\mathrm{O}^{2}$ and Chukw, A. $\mathrm{O}^{3}$ \\ ${ }^{1}$ Department of Animal Production Technology, Imo State Polytechnic Umuagwo, Nigeria. \\ ${ }^{2}$ Department of Agricultural Extension Management Technology, Imo State Polytechnic \\ Umuagwo, Nigeria. \\ ${ }^{3}$ Department of Agricultural Economics and Extension, Imo State University Owerri, Nigeria. \\ *Corresponding author:oshotex2014@yahoo.ca
}

\section{ABSTRACT}

The study assessed constraints to increased layers production among small-scale poultry farmers in Ikwuano Local Government Area of Abia State. Data were collected using a multistage sampling technique to select 120 small-scale poultry farmers. Descriptive statistics (frequencies counts, percentages) were used to describe the socio-economic characteristics of the respondents. The result shows that the mean age of the respondents was 48 years and majority $(77.5 \%)$ of the farmers had higher education. Majority of the respondents (73\%) practiced sweeping and packing of dirt in the poultry house as the daily routine management on their farms. The major constraint faced by the respondents was disease and pest attack (76.7\%) followed by difficulty in credit and loan procurement processes (73.3\%). The study therefore recommends that Government should tackle the problem of loan/credit procurement, market price instability, disease and pest as well as proper funding of small-scale layers poultry business so as to enhance the commercialization of poultry industry in Nigeria.

Keywords: Poultry Farms, Layer Production, Socio-Economic Characteristics, Constraints.

\section{RESUMEN}

El estudio evaluó las limitaciones para aumentar la producción de capas entre los avicultores de pequeña escala en el área del gobierno local de Ikwuano del estado de Abia. Los datos fueron recolectados usando una técnica de muestreo de etapas múltiples para seleccionar 120 avicultores a pequeña escala. Se utilizaron estadísticas descriptivas (conteos de frecuencias, porcentajes) para describir las características socioeconómicas de los encuestados. 
El resultado muestra que la edad promedio de los encuestados fue de 48 años y la mayoría (77.5\%) de los agricultores tenían educación superior. La mayoría de los encuestados (73\%) practicaron barrer y empacar la suciedad en el gallinero como el manejo diario de rutina en sus granjas. La principal limitación que enfrentaron los encuestados fue el ataque de enfermedades y plagas (76.7\%) seguido de dificultades en los procesos de adquisición de créditos y préstamos (73.3\%). Por lo tanto, el estudio recomienda que el Gobierno aborde el problema de la adquisición de préstamos / créditos, la inestabilidad de los precios de mercado, las enfermedades y las plagas, así como la financiación adecuada del negocio avícola de pequeña escala para mejorar la comercialización de la industria avícola en Nigeria.

Palabras clave: granjas avícolas, producción en capas, características socioeconómicas, restricciones.

\section{INTRODUCTION}

Livestock production constitutes an important component of the agricultural economy in developing countries and it is an instrument of socio economic change, improved income and quality of rural life in Nigeria (Olaniyi et al., 2010). Poultry production as an aspect of livestock production is important to the biological needs, economic and social development of the people in any nation (Oladeebo and Ambe-Lamidi 2007). However, the contribution of poultry production (meat and eggs) to total livestock output increased from 26\% in 1995 to $27 \%$ in 1999 with an increase in egg production alone accounting for about $13 \%$ during the period (Ojo, 2003).

The development of the poultry industry has also been described as the fastest means of bridging the protein deficiency gap prevailing in most of the developing countries. The poultry industry, if properly harness can also serve as a source of foreign earnings complementing crude oil which at present constitutes the main source of foreign earnings in Nigeria. In poultry production small scale poultry production represents one of the few opportunities for saving, investment and security against risks. It accounts for approximately $90 \%$ of total poultry production (Branckaert 1999).

Despite the acknowledge importance of poultry production Akanni (2007) opined that it is characterized by low production level due to limited finance for the procurement of basic poultry equipment and materials. The result of this is that many of the small-scale poultry farmers are not encouraged to increase their productivity; thereby moving from small-scale production to a large scale production by small-scale poultry farmers encountered hindrances in the poultry industry which could be detrimental to increase poultry production. The aim of the present study is small-scale poultry farmers in Ikwuano Local Government Area of Abia State, Nigeria. 


\section{MATERIALS AND METHODS}

Study Area: Abia state is one of the states in South East Nigeria. Umuahia is the capital of Abia state. Ikwuano is a Local Government Area of Abia State, Nigeria. Its headquarters is in Isiala - Oboro. It has an area of $281 \mathrm{~km}^{2}$ and a population of 137,993 at the 2006 census. It is made up of about 52 villages and communities and is bounded by Ini LGA of Akwa Ibom State by the West and Umuahia North. Ikwuano Local Government Area is geologically situated in the Eastern Niger Delta and lies within latitudes $5^{\circ} 20^{\prime}$ and $5^{\circ} 32$ ' N, and longitudes $7^{\circ} 32^{\prime}$ and $70^{\circ} 40^{\prime}$ (ABLS, 2015).

Sampling Procedure and Sample Size: From the four agricultural zones in Abia state, Ikwuano zone was purposively selected because of the presence of small-scale poultry farmers in the zone. From the selected zone, 3 blocks were randomly selected. Two cells were selected using simple random technique to make up 6 cells. Two villages were randomly selected from each of the 6 cells to make up 12 villages, from each of the 12 villages. 10 small-scale poultry farmers were randomly selected to make up 120 small-scale poultry farmers. The total sample size for the study was 120 small-scale poultry farmers.

Data Analysis: Data collected was subjected to descriptive inferential statistics; frequency, percentages and means was used to describe data collected.

\section{RESULTS AND DISCUSSION}

Socioeconomic Characteristics of the Respondents Table 1 indicates that most (62.5\%) of the respondents were between the ages of $21-40$ years while $15.8 \%$ are between the ages of 41-60. This implies that small scale layers poultry farming is common among younger farmers unlike those who are above 60 years which represent $1.7 \%$ of the respondents in this study. The ages ranges from 21 to 40 years indicates that majority of the respondents were within the economically active age category and this is in line with Yinusa (1999) who observed that this age bracket contains the innovative, motivated and adaptable individuals. Table 1 indicates that 63.3 percent of the respondents were married while $29.2 \%$ and $7.5 \%$ are single and widowed respectively. Most $(77.5 \%)$ of the respondents had higher education which could probably have encourage them to choose poultry farming not regarding the technicality involved in it although at a small-scale level. Most (63.3\%) of the respondents had more than 2 people in the household. It implies that respondents with family size above 2 people would have more hands to work in their poultry which could aid increase in their output.

Sonaiya (2007) stated that family poultry contributing $68.9 \%$ of the total poultry meat produced in Nigeria. Only 2.5 percent of the respondents generate above 60,000 naira per month from their poultry business. This agree with Akanni (2007) who stated that low income from poultry business is one of the constraints to increased productions faced by small scale 
poultry farmers. Table1 also indicated the level of experience of the respondents; $65 \%$ of the respondents had less than 5 years' experience while $10 \%$ had above 10 years of experience.

Little years of experience could be the reason for low layer production among the smallscale layer farmers. The knowledge on management, which is a key to profitable poultry production, is gained through years of experience of the poultry farmer (Fetuga 1992). Majority $(99.2 \%)$ of the respondents were raising below 50 birds as the time of this research. According to Akanni (2007) most small-scale poultry farmers have limited finance to raise larger number of flocks.

Daily Routine Management Practices: Table 2 shows that 73 percent of the respondents always sweep and pack dirt's within and outside the layers house, 56 percent of them always clean the water troughs and refill it daily, 45.5 percent sometimes weigh and measure the quantity of feed given to the layers. Although, 65.5 percent of the respondents sometimes cull unhealthy birds but 61.5 percent of the respondents do not practice foot dip system at the layers house. This implication of this is that small scale poultry farmers sometimes ignore some management practices as not important which could have hazards effect on their layers production performances.

Most $(61 \%)$ of the respondents keep records of egg laid for the day, this will help them to have adequate knowledge of the number of egg produced and also know the likely number of layer that are yet to produce after reaching the laying age. Separation of cracked egg was one of the daily routine management practices carried out by 71 percent of the respondents. This is necessary so as to prepare the eggs that were not cracked for sale each of the day. Since, cleaning and preparing the egg for sale will generate income; most of the layers farmers would always be willing to engage in such management practices. Good management practices are the minimum care that is required to humanely maintain the birds. Caring for the birds and tending to their basic needs is a constant responsibility-24 hours a day, 7 days a week (Claucer, 2010).

Perception of the Layers Farmers on Benefit of Increased layer Production: From Table 3 most $(60 \%)$ of the respondents strongly agreed that the increases in the number of layers will help to increase profit that will be made from the poultry business. More than half of the respondents perceived that increase in the layers production will increase the egg production, poultry meat availability and more poultry droppings would be produced which could be used as manure to boost agricultural production. They also agreed that increase in layer production will improves well-being of the farmer's household.

Village chickens play a very important role in the livelihoods of those people keeping them. These chickens have a multitude of functions, and these include the many cultural and traditional roles, food and income generation (Scoones 1992; Kusina and Kusina 1999). At least 40 percent concurred that increase in layer production could create job opportunity because it will require more labour to handle the increase in the poultry business. Among the 
respondents (26.7\%) strongly disagree that there is adequate government policy for that could support them to boost their layer production and $33.3 \%$ of the respondents also disagree that loans are easily accessed when their layer productions increases. This implies that the fact that one has a large number of egg producing birds do not guarantee that one will have access to loan.

Table 1 : Socio -economic characteristics of respondents Variables Frequency Percentage

Sex

Male 73

60.8

Female

47

39.2

Age (years)

Less than 20

24

20

$21-40$

75

62.5

$41-60$

19

15.8

Marital Status

Single married

35

29.2

Married

76

63.3

Widowed

9

7.5

Level of education

No formal education

Adult literacy 1

Primary education $\quad 17$

2.5

$\begin{array}{ll}1 & 0.8\end{array}$

Secondary

Education

6

14.2

Higher education 93

5.0

Family size

1

2

More than 2

76

29.2

Monthly Income

Less than 20,000

$20,000-40,000$

43

52.5

$41,000-60,000$

38.3

Above 60,0000

8

6.7

Years of Experience

Less than 5 years

3

2.5

$5-10$ years

78

65

Above 10 years

30

25

Number of birds

$20-30$

68

56.7

$31-40$

25

20.8

$41-50$

17

14.2

$51-60$

10

8.3 
Table 2: Daily Routine Management Practices

\begin{tabular}{|c|c|c|c|}
\hline \multicolumn{4}{|l|}{ Daily Routine Management Practices } \\
\hline $\begin{array}{l}\text { Sweeping and packing dirts within and } \\
\text { outside the layer house. }\end{array}$ & 73.0 & 20.0 & 7.0 \\
\hline $\begin{array}{l}\text { Thoroughly clean water troughs and } \\
\text { refill with clean water. }\end{array}$ & 56.0 & 40.7 & 3.3 \\
\hline $\begin{array}{l}\text { Weigh/measure the quantity of feed } \\
\text { given to the layers. }\end{array}$ & 20.9 & 45.5 & 33.6 \\
\hline Add fresh feed into the feed troughs. & 63.8 & 33.8 & 2.4 \\
\hline Collect eggs at least three times a day. & 56.7 & 40.5 & 2.8 \\
\hline Keep records of eggs laid for the day. & 61.4 & 33 & 5.6 \\
\hline Check for sick layers & 25.5 & 66.8 & 7.7 \\
\hline Cull unhealthy layers from others. & 29.2 & 65.5 & 6.3 \\
\hline check for mortality and remove them & 47.5 & 51.5 & 1.0 \\
\hline Change the foot dip. & 15.5 & 23 & 61.5 \\
\hline $\begin{array}{l}\text { Record number of unhealthy birds and } \\
\text { drug administered }\end{array}$ & 23.3 & 19.2 & 58.5 \\
\hline Separate cracked eggs, leakers and thin & & & \\
\hline eggs after gathering. & 71.4 & 27.6 & 1.0 \\
\hline
\end{tabular}

NB: $A=$ Always. $S=$ Sometimes. $N=$ Never .

Twenty $(20 \%)$ of the respondents strongly agree that with increase in layer production there is more possibility that they will have access to loan because their large number of birds can encourage the funders to finance their business.

Constraints to Increase of Layers Production: Table 4 Shows that $76.7 \%$ of the respondents poultry was faced with diseases and pest attack as a major constraint, this is probably because most of small scale poultry farmer could not identify the symptoms of disease earlier enough to prevent disease outbreak which is a major threat that wipe out many of the poultry in developing countries.

Most $(73.3 \%)$ of the respondents were also faced with uneasy access to constraints to increase of layers production loan and credit procurement; this was in line with reports of Agbato,1997; Akeeb, 1997; Adebayo and Adeola (2005) also confirmed that credit facilities or loans from financial institutions are not accessible to the poultry farmers in the rural area. Market price fluctuation and non-availability of land and space were also pointed by the respondents as constraints to increase of layer production. Meanwhile, 56 percent of the respondents lack technical knowledge required in the poultry business, Olaniyi et al. (2008) opined that lack of technical knowledge is a major constraint that militates against poultry production.

More than 55.8 percent of the respondents indicated that rate of mortality of their laying is a major constraint to increase their layer production. This concurs with Chitate and Guta (2001) and Smith (1992) who also observe that mortality was the major constraint to village chicken productivity. Lack of quality ingredient for feed formulation was also indicated by 55.8 percent of the respondents to be a major constraint while 51.7 percent believed that the high 
cost of feed for their layering birds was a major constraint encountered which prevented them from increasing their layers production. The high cost of feed could be linked also to the lack of quality ingredient for feed formulation because the available quality ingredient may be costly and thereby affecting the price of the feed. The implication of this is that if the cost of feed is high and small scale poultry farmer could not afford it then it will affect the number of birds they can keep.

Lack of feed for the mother hen and the chicks was the main reason for not confining poultry birds, chick confinement has been known to reduce losses from predators; however, it comes at a cost to the farmer in terms of increased feed (Sonaiya and Swan, 2004).

Table 3 : Perceived Benefit to Increased production of Layers in the study Area

\begin{tabular}{|c|c|c|c|c|c|c|}
\hline \multirow[t]{3}{*}{$\mathrm{S} / \mathrm{N}$} & \multirow[t]{3}{*}{ Perceived Benefits } & SD & $\mathrm{D}$ & $U$ & A & SA \\
\hline & & Freq & Freq & Freq & Freq & freq \\
\hline & & $\%$ & $\%$ & $\%$ & $\%$ & $\%$ \\
\hline \multirow[t]{2}{*}{1.} & \multirow[t]{2}{*}{ Increase in number of layers increases profit/income. } & 2 & 33 & 2 & 23 & 60 \\
\hline & & 1.7 & 27.5 & 1.7 & 19.2 & 50.0 \\
\hline \multirow[t]{2}{*}{2.} & \multirow[t]{2}{*}{ Increase in number of layers increases egg production. } & 15 & 20 & 8 & 31 & 46 \\
\hline & & 12.5 & 16.7 & 6.7 & 25.8 & 38.3 \\
\hline \multirow[t]{2}{*}{3.} & \multirow{2}{*}{$\begin{array}{l}\text { Poultry meat production increases with the increased } \\
\text { number of layers reared. }\end{array}$} & 16 & 15 & 18 & 48 & 23 \\
\hline & & 13.3 & 12.5 & 15 & 40 & 19.2 \\
\hline \multirow[t]{2}{*}{4.} & \multirow{2}{*}{$\begin{array}{l}\text { There is more supply of poultry droppings for manure } \\
\text { with the increased number of layers reared which can } \\
\text { boost organic agriculture. }\end{array}$} & 26 & 5 & 25 & 38 & 26 \\
\hline & & 21.7 & 4.2 & 20.8 & 31.7 & 21.7 \\
\hline \multirow[t]{2}{*}{5.} & \multirow{2}{*}{$\begin{array}{l}\text { Well-being of the farmer and his family improves when } \\
\text { the number of layers increases. }\end{array}$} & 23 & 14 & 21 & 32 & 30 \\
\hline & & 19.2 & 11.7 & 17.5 & 26.7 & 17.5 \\
\hline \multirow[t]{2}{*}{6.} & \multirow{2}{*}{$\begin{array}{l}\text { Less amount of money is spent in transporting of the } \\
\text { layers and eggs when the number of layers increases. }\end{array}$} & 27 & 42 & 11 & 30 & 10 \\
\hline & & 22.5 & 35 & 9.2 & 25.0 & 8.3 \\
\hline \multirow[t]{2}{*}{7.} & \multirow{2}{*}{$\begin{array}{l}\text { Increase in the number of layers reared will improve the } \\
\text { protein consumption rate in the economy. }\end{array}$} & 20 & 38 & 11 & 38 & 13 \\
\hline & & 16.7 & 31.7 & 9.2 & 31.7 & 10.8 \\
\hline \multirow[t]{2}{*}{8.} & \multirow{2}{*}{$\begin{array}{l}\text { Loans and credits are easily accessed when the number } \\
\text { of layers reared increases. }\end{array}$} & 26 & 40 & 8 & 36 & 10 \\
\hline & & 21.7 & 33.3 & 6.7 & 30 & 8.3 \\
\hline \multirow[t]{2}{*}{9.} & \multirow{2}{*}{$\begin{array}{l}\text { There is adequate government policy intervention for } \\
\text { poultry farmers rearing an increased number of layers. }\end{array}$} & 32 & 28 & 19 & 25 & 16 \\
\hline & & 26.7 & 23.3 & 15.8 & 20.8 & 13.3 \\
\hline \multirow[t]{2}{*}{10.} & \multirow{2}{*}{$\begin{array}{l}\text { Job opportunities increases with the increase number of } \\
\text { layers reared. }\end{array}$} & 4 & 8 & 60 & 24 & 24 \\
\hline & & 3.3 & 6.7 & 50 & 20.0 & 20.0 \\
\hline
\end{tabular}

NB: SD = Strong Disagree, $D=$ Disagree, $U$ = Undecided, A= Agree, SA = Strongly Agree 
Sustainability, Agri, Food and Environmental Research, (ISSN: 0719-3726), 8(3), 2020: 194-204 http://dx.doi.org/10.7770/safer-V0NO-art1989

Table 4. Constraints to Increase in Production of Layers

\begin{tabular}{|c|c|c|c|c|c|c|}
\hline \multirow[t]{2}{*}{ Constraints } & \multicolumn{2}{|c|}{ Major Constraints } & \multicolumn{2}{|c|}{ Minor Constraints } & \multicolumn{2}{|c|}{ No Constraints } \\
\hline & Freq & $\%$ & Freq & $\%$ & Freq & $\%$ \\
\hline Disease and pest attack & 92 & 76.7 & 27 & 22.5 & 1 & 0.8 \\
\hline Cost of drugs and vaccination & 72 & 60.0 & 45 & 37.5 & 3 & 2.5 \\
\hline Market/price fluctuation & 70 & 58.3 & 36 & 30.0 & 14 & 11.7 \\
\hline Accessibility of feed & 51 & 42.5 & 45 & 37.5 & 24 & 20.0 \\
\hline Availability of labour & 25 & 20.8 & 36 & 30.0 & 59 & 49.2 \\
\hline Unavailability of land/space & 30 & 25.0 & 69 & 57.5 & 21 & 17.5 \\
\hline $\begin{array}{l}\text { Difficulty in credit and loan } \\
\text { procurement processes }\end{array}$ & 88 & 73.3 & 20 & 16.7 & 12 & 10.0 \\
\hline $\begin{array}{l}\text { Purchase of healthy day old } \\
\text { chicks }\end{array}$ & 65 & 54.2 & 36 & 30.0 & 19 & 15.8 \\
\hline Cost of feed & 62 & 51.7 & 50 & 41.7 & 8 & 6.7 \\
\hline Rate of mortality of the layers & 67 & 55.8 & 49 & 40.8 & 4 & 3.3 \\
\hline $\begin{array}{l}\text { Packing and disposal of the } \\
\text { layers droppings }\end{array}$ & 56 & 46.7 & 48 & 40.0 & 16 & 13.3 \\
\hline $\begin{array}{l}\text { Lack of quality ingredient for } \\
\text { feed formulation }\end{array}$ & 67 & 55.8 & 44 & 36.7 & 9 & 7.5 \\
\hline $\begin{array}{l}\text { Lack of technical know-how in } \\
\text { handling poultry }\end{array}$ & 68 & 56.7 & 35 & 29.2 & 17 & 14.2 \\
\hline
\end{tabular}

Freq $=$ Frequency; \% = Percentage

Possible Solutions to the Constraints to Increase Layers Production: Table 5 indicates the respondents' likely solution to the various constraints that affect the increase in production of layers. About 50 percent of the respondents indicated that provision of easy access to loan procurement will proffer solution to the constraints they are facing in increasing layer production. This is in line with Haruna et al.(2007) who opined that small-scale layer farmers do not have adequate capital and resources to expand their scale of operations. Some (24.2\%) of the respondents pointed out that stable market price for the sale of egg could also encourage poultry farmers to increase their production since they are assured that they will be able to sell their eggs at a good price to the people regardless of season they produce more egg because there is stable market price for the sale of egg.

Provision of adequate land and space for poultry production was suggested as a solution by 16.7 percent of the respondents, although it is a few proportion that indicated that provision of land/space will assist in increasing layers poultry production but it is a vital suggestion because without land, poultry farms cannot be established and where it is proposed to be sited close to residential buildings most of the times the residents of such area protest about the location of poultry in their neighbourhood.

Knowledge and technical know-how in any business is very important so as to be able to handle such business properly and efficiently, 10.8 percent of the respondents indicated that adequate training should be provided so as to educate and enlighten the farmers. Meanwhile, only $4.2 \%$ of the respondents indicated that the provision of quality ingredients for poultry feed will proffer solutions to the constraints faced by the farmers. 
It is probably because many of the small-scale poultry farmers mostly at times purchase feed they utilized for their birds. So if there is more supply of the quality ingredient for formulation and compounding, then the constraint of high cost of feed may reduce and the respondents will be able to buy either more of the ingredient for feed compounding or buy more feed to nourish their laying poultry birds production.

Table 5. Possible Solutions to the Constraints to Increased Layers Production

\begin{tabular}{lll}
\hline Possible Solution & Frequency & Percent \\
\hline Easy access to credit / loan procurement & 53 & 44.2 \\
Stable market price for sale of egg. & 29 & 24.2 \\
Provision of adequate land / space for poultry production & 20 & 16.7 \\
Provision adequate training in handling poultry & 13 & 10.8 \\
Provide quality feed ingredients & 5 & 4.2 \\
\hline
\end{tabular}

As coclusions, the challenges facing the small poultry farms especially the layers poultry farms impede the willingness of the poultry farmer to increase their production. The study established that majority of the respondents in the study area were young and educated which could help them to be innovative. They also perceived that there would be increased profit if they can increase their layer production which could help them to improve their wellbeing and raise their standard of living.

Meanwhile some of the daily management practices that could promote hygiene were ignored and the major constraints that militating the increase of layer production as identified by this study were disease and pest outbreak, non-availability of credit/loan facilities as well as the lack of technical know-how to handle the poultry profitable.

It is therefore recommended that small-scale layer poultry farmers should be encouraged to form cooperative societies or join the existing one to be able to access loan to their business and government could also make fund available to assist the layers poultry farmers. Capacity training of poultry farmers to enable them to cope with the challenges of modern poultry farming and commercialization of small scale layers poultry production should be carried out.

Government should make policies specifically for transformation of the small scale poultry industry. This will assist in removing the challenges of small poultry farms and thereby creating a favourable environment to increase layer production among small holder poultry farmers. 
Sustainability, Agri, Food and Environmental Research, (ISSN: 0719-3726), 8(3), 2020: 194-204 http://dx.doi.org/10.7770/safer-V0NO-art1989

\section{REFERENCES}

Abia State Ministry of Lands and Survey (ABLS) (2015). Longitudes and Latitudes locations of Ikwuano Local Government Area of Abia State, Nigeria.

Adebayo, O.O. \& R.G. Adeola 2005. Socio Ejigbo local Government Area of Osun State. Journal of Human Ecology 18 (1): 39-41.

Agbato, O. A. 1997. Effective Strategies for Egg Marketing in Nigeria. Paper Presented At A Workshop Organised by The Nigeria Society For Animal Production (NSAP), Ogun State, Nigeria.

Akanni, I.A., 2007. Effect of micro-Finance on Small Scale Poultry business in South Western Nigeria. Emirate Journal of Food and Agriculture, 19(2): 38-47

Akeeb, S. 1997 Problems of Poultry Production in Nigeria. Paper Presented At Workshop A Organised By The Nigeria Society For Animal Production NSAP), Ogun State, Nigeria.

Branckaert, J.A. 1999. Constraints in poultry production among smallholders. Journal of Agricultural Science, 38: 387-399

Central Bank of Nigeria. 2010. Central Bank of Nigeria. Annual Report Statement of Account Statistical Bulletin.

Chitate F. \& Guta M. 2001. Country report: Zimbabwe. In: SADC Planning Workshop on Newcastle Disease Control in Village Chickens (Alders R G and Spradbrow P B, Editors). Proceedings 103. Aciar. Canberra. Australia, pp. 46- 46-50.

Emaikwu, K.K., Chikwendu, D.O. \& Sanni, A.S. 2011. Determination of Flock size in Broiler Production in Kaduna State of Nigeria. Journal of Agricultural Extension and Rural Development. 3(1): 202-211

Fetuga B.L. 1992. Farmers: A Case Study of Aiyedoto Farm Settlement. Nigeria. Research Journal of Agricultural Biological Sciences, 2(6): 256-261.

Food and Agricultural Organisation-FAO. 1995.. Utilization of Poultry Feed Resources by Smallholders in villages in Developing Countries. Food and Agricultural Organization of the United Nations, Rome, Italy. http//faosta.fao.org

Food and Agricultural Organisation-FAO. 2003. Statistical Data base of Food and Agricultural Organization of the United Nations, Rome, Italy. http//faosta.fao.org

Haruna, U., Jibril, S.A., D.J., U. Kalla \& H. Suleiman, 2007. Evaluation of Egg Production in Jos North Local Government Area, Plateau State, Nigeria. International Journal of Poultry Science, 6: 604-607.

Kusina, J.F. and Kusina, N.T. 1999. Feasibility study of agricultural and household activities as they relate to livestock production in Guruve District of Mashona land Province with emphasis on poultry production. Report for the Household Agricultural Support Programme (HASP), Zimbabwe, September 1999.

NBS 2006. National Bureau of Statistics, Nigeria Census Population 2006. 
Ojo, S.0. 2003. Productivity and Technical Efficiency of Poultry Egg Production in Nigeria. International Journal of Poultry Science, 2: 459- 464.

Oladeebo J.O. \& A.I. Ambe-Lamidi. 2007. Profitability, Input Elasticity and Economic Efficiency of Poultry Production among Youth Farmers in Osun State, Nigeria International Journal of Poultry Science 6 (12): 994-998 PSN 2009.

Olaniyi, O.A, I.O. Adesiyan \& R.A. Ayoade. 2008. Constraints to Utilization of Poultry Production Technology among Farmers in Oyo State, Nigeria. Journal Human Ecology 24(4): 305309

PSN 2009. Poultry site News: http://'poultry newsdesk.com.

Scoones, I. 1992. The Economic Value of Livestock in a Communal Area in Southern Zimbabwe. Agricultural Systems, 39: 339-359.

Smith A. J. 1992. Integration of Poultry Production into the Agricultural Systems in the Tropical Agriculturist: Poultry. CTA; Macmillan. Pp 176- 191

Sonaiya, E. B. and Swan, S. E. J. 2004. Small-Scale Poultry Production. Technical guide. FAO Animal Production and Health Manual 1, Rome, Italy.

Sonaiya, E.B 2007. Family Poultry Food Security and the Impact of HPAI. World Poultry Science Journal, 63: 132-138.

Yinusa. M.B 1999. North farms alone: A study of rural livelihoods in the middle belt of Nigeria. DARE ASLD working paper 38.

Received:18 ${ }^{\text {th }}$ Jule 2019; Accepted: $12^{\text {th }}$ December 2019; First distribution: $3^{\text {th }}$ December 2019; Final publication: 01th September 2020. 